\title{
NSMAF Gene
}

National Cancer Institute

\section{Source}

National Cancer Institute. NSMAF Gene. NCI Thesaurus. Code C104584.

This gene is involved in TNF-mediated cell signaling. 